\title{
Correlation studies on seed quality traits in diverse genotypes of finger millet (Eleusine coracana (L.) Gaertn)
}

\author{
Shivangi Negi ${ }^{1 *}$, Vineet Kumar ${ }^{2}$ and Abhishek Panwar ${ }^{1}$ \\ ${ }^{1}$ Department of Seed Science and Technology, VCSG University of Horticulture and Forestry, \\ Bharsar (Uttarakhand), India \\ ${ }^{2}$ Department of Crop Improvement, VCSG Uttarakhand University of Horticulture and \\ Forestry, Bharsar (Uttarakhand), India \\ *Corresponding author
}

Keywords

Genotypes, finer millet, variance, vigour, germination, correlation

Article Info

Accepted:

10 August 2019 Available Online:

10 September 2019
The thirty-five diverse genotypes of finger millet including three checks viz., PRM-1, PRM-2 and VL-149 for seed quality parameters at seed testing laboratory of the department of seed science and technology, College of Forestry, Ranichauri Campus, V. C. S. G. Uttarakhand University of Horticulture and Forestry. The data on 14 quantitative traits viz., first count, standard germination, root length, shoot length, seedling length, seedling fresh weight, seedling dry weight, relative growth index, vigour index-I and vigour index-II were collected randomly from 10 seedlings form each genotypes. Genotype IC-308884 was highest for seedling length, vigour index-I and vigour index-II. Genotype IC-354383 was observed maximum germination percentage and relative growth index. Analysis of variance revealed highly significant among the germplasm for all the characters. Correlation studies revealed that all the traits of seed quality were associated with each other in terms of vigour. Seedling vigour-II exhibited very strong and positive correlation with seedling dry weight, seedling fresh weight and seedling vigour index-I while seedling vigour index-I showed highly significant and positive correlation with seedling length, root length, shoot length and standard germination. It is manifest that before assessment of seedling vigour, standard germination and seedling dry weight of the seed lots in any genotype could be used to envisage the yield potentiality of that genotype in open field conditions. 


\section{Introduction}

Finger millet locally known as "Ragi" or "Madua" (Eleusine coracana L.) is the most important among small millets and possesses the potentialities to be exploited to meet crying need of dry land farmers (Kumari et al., 2015). Finger millet (Eleusine coracana (L.) Gaertn. $2 \mathrm{n}=4 \mathrm{x}=36$ ) belongs to the family Poaceae, and is widely cultivated in the arid and semi-arid regions of the world. The term Eleusine is derived from Eleusis, an old epic city sacred to Demater, the greek deity presiding over agriculture. The term coracana is derived from kurukkan, the singhali name of the grain. It is cultivated mostly as a rainfed crop for its valued food grains, dry fodder and adaptability to wide range of geographical areas (Ulaganathan and Nirmalkumari, 2014). Ragi is commonly called as "Nutritious millet" as the grains are nutritionally superior to many cereals. It contains almost all the nutrients like protein (9.2 per cent), carbohydrates (76.32 per cent) and fat (1.29 per cent). It is very rich in minerals (2.70 per cent) such as calcium $(452 \mathrm{mg} / 1000 \mathrm{~g})$, iron $(3.90 \mathrm{mg} / 100 \mathrm{~g})$ and ash (3.90 per cent) which are the core ingredients of normal human diet (Pandey and Kumar, 2005; Negi et al., 2017). Being rich in protein, iron and calcium, finger millet severs as an important staple food for rural populations in developing tropical countries where calcium deficiency and anaemia are widespread (Owere et al., 2015).

High quality seed is essential and desirable to ensure good crop establishment. For many field crops, one of the main problems observed is poor crop stand establishment of which is influenced by seed quality, adverse climatic condition, poor field management etc. (Maiti et al., 2002). Establishment of seedling is extremely important in determining the yield of crop in short period of time (Misra, 1990 and Misra et al., 2002).
The rate and degree of seedling establishment are extremely important factors in determining both yield and time of maturity (Briggs \& Aylenfishu, 1979). Therefore, seed quality evolution is essential for a plant breeder to enhance the yield. Seed is the essential element in agriculture upon which the success of any crop production programme depends. Thus, seed quality testing has a great importance for the evaluation of varietal superiority in the given environment (Kumar et al., 2015). Laboratory seed tests aim to provide accurate and reproducible guidance, rather than absolute answers or predictions. Viability, germination and vigour tests all produce results that are usually greater than, and at best equal to, how the seed will actually perform in the field. An appreciation of what viability, germination and vigour measure can help and maximize the understanding of the planting value or storage potential of seed (Kumar et al., 2017).

\section{Materials and methods}

The experiment material for the present study was taken to evaluate thirty-five genotypes of finger millet including three checks PRM-1, PRM-2 and VL-149. The experiment was conducted in the seed testing laboratory of the Department of Seed Science and Technology, College of Forestry, V. C. S. G. Uttarakhand University of Horticulture and Forestry. In the present study fifty seeds in four replication were germinated on top of the paper at $25^{\circ} \mathrm{C}$ in seed germinator for 14 days. The papers were moistured with $0.2 \% \quad \mathrm{KNO}_{3}$ solution instead of water to break seed dormancy (ISTA, 1996). At final day of germination normal seedling counted which determine the germination percentage. For the determination of seedling length. Ten seedlings were taken from each replication in all the treatment. Theses seedlings were measured with help of scale. Seed vigour index determined with the multiplication of seed germination and 
seedling length. For the determination of seedlings vigour 10 seedlings in each replication in all the varieties were dried at $80^{\circ} \mathrm{C}$ for twenty four hours in oven. The standard germination test was conducted according to rule of International Seed Testing Association and normal seedlings were expressed as percent germination. Seed vigour index was calculated according to the method (Abdul and Anderson, 1973).

\section{Result and Discussion}

\section{Analysis of variance}

Analysis of variance revealed highly significant among the germplasm for all the characters such as first count $(\%)$, standard germination $(\%)$, shoot length $(\mathrm{cm})$, seedling length $(\mathrm{cm})$, seedling fresh weight $(\mathrm{g})$, seedling dry weight $(\mathrm{g})$, relative growth index (RGI), seedling vigour index-I and seedling vigour index-II were presented in Table 1. The mean for the characters were significantly different for all finger millet genotypes.

\section{Mean performance of genotypes for seed quality traits}

The genotypes IC-308884 was highest for seedling length, vigour index-I and vigour index-II while the genotype IC-354383 was highest for maximum germination percentage (), relative growth index and mean daily germination. The mean value of various quality parameters for finger millet genotypes in given in Table 2.

The germination per cent one of the most important characteristics of seed to be used for estimation of planting value. Germination seems to be biological process depending on several factors including the differential behaviour of genotypes.

The difference might be due to the genetic makeup of each genotypes. Similar results also reported by Krishnanappa et al., (2001) from $23.00 \%$ to $86.0 \%$ in finger millet and Tzortzakis (2009) from $73.00 \%$ to $91.00 \%$, Kumar et al., (2015) from $44.25 \%$ to $93.75 \%$ in grain amaranth.

\section{Correlation studies}

Correlation coefficient which provides symmetrical measurement of degree of association between two variables or characters, help us in understanding the nature and magnitude of association among yield and yield components. The assessment of seed viability and vigour traits by growing the seed samples of different genotypes in the laboratory condition before sowing in main field and further estimation of performance in field conditions enables to establish relationship between seed quality parameters and field performance. With the help of such relations, the potentiality of seed lot of a genotype could be assumed in advance (Panwar et al., 2018). The estimates of correlation coefficients among different pairs of seed quality traits have been presented in Table 3.

The results showed that seedling length exhibited highly significant and positive correlation with root length (0.9484), shoot length (0.8860) and significant positive correlation with first count (0.3746) and standard germination (0.3479) while seedling vigour index-II showed highly significant positive association with seedling dry weight (0.9338), seedling fresh weight (0.6010), seedling vigour index-I (0.4672) and significant positive association with root length (0.4148), seedling length (0.3859) and standard germination (0.3741).

Relative growth index (RGI) showed highly significant and positive correlation with first count (0.9286) followed by standard germination (0.6640), seedling vigour index-I 
(0.5421) and significant positive correlation with shoot length (0.3569) and seedling length (0.3478).

Seedling vigour index-I possessed highly significant positive association with seedling length (0.9132), root length (0.8542), shoot length (0.8286), standard germination (0.6929) and first count (0.6580) while standard germination showed highly significant and strong positive correlation with first count (0.8808). Seedling dry weight showed highly significant and positive correlation with seedling fresh weight
(0.7273) while shoot length possessed higher positive and significant correlation with root length (0.6958) and significantly positive correlation with first count (0.3794) and standard germination (0.3727). Seedling fresh weight showed highly significant and positive association with seedling length $(0.4578)$ and root length (0.4555). However, root length observed significant positive association with first count (0.3271). Similar results were also observed by Yadav and Dhankar, 2001; Deshraj, 2002; Punia et al., (2006); Kumar et al., (2017) and Panwar et al., (2018).

Table.1 Analysis of Variance (ANOVA) for seed quality traits of finger millet genotypes

\begin{tabular}{|l|c|c|}
\hline \multirow{2}{*}{ Characters } & \multicolumn{2}{|c|}{ Mean sum of square (MSS) } \\
\cline { 2 - 3 } Degree of freedom & Treatment & Error \\
\hline First count (\%) & 34 & 105 \\
\hline Standard germination (\%) & $150.94 * *$ & 2.41 \\
\hline Root length (cm) & $165.22 * *$ & 4.44 \\
\hline Shoot length (cm) & $3.04 * *$ & 0.00086 \\
\hline Seedling length (cm) & $1.39 * *$ & 0.00352 \\
\hline Seedling fresh weight (g) & $7.27 * *$ & 0.00744 \\
\hline Seedling dry weight (g) & $0.00410 * *$ & 0.000075 \\
\hline Relative growth index (RGI) & $0.00149 * *$ & 0.00000668 \\
\hline Seedling Vigour Index-I & $88.09 * *$ & 5.90 \\
\hline Seedling Vigour Index-II & $86631.53 * *$ & 462.17 \\
\hline * Significant at $0.5 \%$ level; & $11.06 * *$ & 0.1261 \\
\hline
\end{tabular}


Table.2 Mean performance of finger millet (Elusine coracana (L.) Gaertn.) genotypes for seed quality traits

\begin{tabular}{|c|c|c|c|c|c|c|c|c|c|c|c|}
\hline S.No. & $\begin{array}{l}\text { Characters } \\
\text { Genotypes }\end{array}$ & $\begin{array}{c}\text { First } \\
\text { count } \\
(\%)\end{array}$ & $\begin{array}{c}\text { Standard } \\
\text { germination } \\
(\%)\end{array}$ & $\begin{array}{l}\text { Root } \\
\text { length } \\
(\mathrm{cm})\end{array}$ & $\begin{array}{c}\text { Shoot } \\
\text { length } \\
\text { (cm) }\end{array}$ & $\begin{array}{l}\text { Seedling } \\
\text { length } \\
\text { (cm) }\end{array}$ & $\begin{array}{l}\text { Seedling } \\
\text { fresh } \\
\text { weight (g) }\end{array}$ & $\begin{array}{c}\text { Seedling } \\
\text { dry } \\
\text { weight (g) }\end{array}$ & $\begin{array}{l}\text { Seedling } \\
\text { Vigour } \\
\text { Index-I }\end{array}$ & $\begin{array}{c}\text { Seedling } \\
\text { Vigour } \\
\text { Index-II }\end{array}$ & $\begin{array}{c}\text { Relative } \\
\text { growth index } \\
\text { (RGI) }\end{array}$ \\
\hline 1 & IC-308917 & 38.66 & 86.00 & 5.08 & 3.64 & 8.73 & 0.179 & 0.060 & 751.06 & 5.16 & 44.62 \\
\hline 2 & IC-520490 & 41.33 & 88.66 & 5.72 & 4.23 & 9.95 & 0.185 & 0.087 & 882.85 & 7.01 & 46.62 \\
\hline 3 & EC-130783 & 29.33 & 76.66 & 6.34 & 3.40 & 9.93 & 0.265 & 0.125 & 761.52 & 9.58 & 38.25 \\
\hline 4 & IC-308905 & 35.33 & 78.66 & 6.05 & 4.05 & 10.10 & 0.192 & 0.080 & 794.82 & 6.32 & 44.96 \\
\hline 5 & IC-354317 & 36.00 & 79.33 & 5.55 & 3.49 & 9.05 & 0.173 & 0.046 & 717.72 & 3.67 & 45.40 \\
\hline 6 & IC-3522490 & 30.66 & 72.66 & 5.64 & 3.67 & 9.31 & 0.181 & 0.074 & 677.02 & 5.40 & 42.16 \\
\hline 7 & IC-3543177 & 26.66 & 70.00 & 5.96 & 3.99 & 9.96 & 0.287 & 0.131 & 690.59 & 9.10 & 38.51 \\
\hline 8 & EC-3522489 & 37.33 & 82.00 & 6.99 & 4.43 & 11.43 & 0.212 & 0.092 & 937.47 & 7.62 & 45.56 \\
\hline 9 & EC-522489 & 40.66 & 85.33 & 5.77 & 4.03 & 9.80 & 0.197 & 0.087 & 836.48 & 7.47 & 47.72 \\
\hline 10 & IC-308771 & 37.66 & 86.66 & 5.02 & 3.63 & 8.65 & 0.153 & 0.069 & 750.27 & 6.16 & 43.03 \\
\hline 11 & IC-354384 & 28.66 & 70.66 & 4.77 & 2.20 & 6.97 & 0.162 & 0.082 & 493.06 & 5.82 & 40.70 \\
\hline 12 & EC-522482 & 33.33 & 80.66 & 4.71 & 3.63 & 8.34 & 0.179 & 0.065 & 673.43 & 5.52 & 41.31 \\
\hline 13 & IC-354422 & 45.33 & 89.33 & 6.13 & 4.10 & 10.24 & 0.200 & 0.091 & 914.79 & 8.16 & 50.75 \\
\hline 14 & IC-308853 & 25.33 & 71.33 & 4.33 & 3.06 & 7.40 & 0.145 & 0.088 & 528.08 & 6.27 & 35.53 \\
\hline 15 & IC-354383 & 52.66 & 96.66 & 7.22 & 3.97 & 11.21 & 0.161 & 0.087 & 1083.67 & 8.47 & 54.47 \\
\hline 16 & IC-354381 & 33.00 & 82.66 & 4.87 & 3.77 & 8.64 & 0.207 & 0.093 & 714.56 & 7.74 & 40.88 \\
\hline 17 & EC-522488 & 36.66 & 84.00 & 5.08 & 4.01 & 9.31 & 0.169 & 0.064 & 782.66 & 5.38 & 43.66 \\
\hline 18 & IC-354410 & 34.00 & 74.66 & 6.97 & 4.01 & 10.99 & 0.208 & 0.069 & 820.35 & 5.15 & 45.72 \\
\hline 19 & IC-308928 & 40.00 & 84.66 & 6.07 & 3.54 & 9.61 & 0.185 & 0.085 & 794.69 & 7.20 & 45.83 \\
\hline 20 & IC-257855 & 42.66 & 88.00 & 4.10 & 3.08 & 7.18 & 0.128 & 0.078 & 632.26 & 6.86 & 48.49 \\
\hline 21 & IC-257863 & 34.66 & 78.00 & 5.22 & 3.12 & 8.34 & 0.188 & 0.074 & 650.98 & 5.79 & 43.64 \\
\hline 22 & IC-308899 & 32.66 & 73.33 & 5.99 & 4.10 & 10.10 & 0.152 & 0.064 & 740.98 & 4.72 & 44.57 \\
\hline 23 & IC-308916 & 31.33 & 74.00 & 6.04 & 3.82 & 9.86 & 0.193 & 0.065 & 729.64 & 4.67 & 42.35 \\
\hline 24 & IC-308849 & 34.66 & 83.33 & 6.36 & 3.97 & 10.33 & 0.224 & 0.104 & 861.31 & 8.69 & 41.65 \\
\hline 25 & IC-308884 & 47.33 & 91.33 & 7.89 & 5.00 & 12.89 & 0.245 & 0.125 & 1177.85 & 11.47 & 53.89 \\
\hline
\end{tabular}




\begin{tabular}{|c|c|c|c|c|c|c|c|c|c|c|c|}
\hline 26 & IC-308883 & 38.66 & 87.33 & 5.92 & 3.96 & 9.88 & 0.154 & 0.070 & 863.44 & 6.14 & 44.27 \\
\hline 27 & IC-308853 & 30.66 & 81.33 & 5.65 & 3.89 & 9.54 & 0.163 & 0.063 & 788.98 & 5.21 & 39.69 \\
\hline 28 & IC-308868 & 26.66 & 77.33 & 6.38 & 3.26 & 9.65 & 0.169 & 0.068 & 746.45 & 5.25 & 34.48 \\
\hline 29 & IC-308878 & 41.33 & 86.00 & 5.59 & 3.05 & 8.64 & 0.164 & 0.063 & 743.04 & 5.41 & 48.05 \\
\hline 30 & EC-522495 & 42.00 & 86.66 & 6.71 & 4.79 & 11.50 & 0.183 & 0.057 & 996.94 & 4.94 & 48.44 \\
\hline 31 & IC-354407 & 30.00 & 80.00 & 6.97 & 4.99 & 11.96 & 0.195 & 0.069 & 973.02 & 5.61 & 36.88 \\
\hline 32 & EC-522485 & 36.66 & 85.33 & 6.60 & 4.15 & 10.68 & 0.179 & 0.084 & 919.05 & 7.28 & 42.63 \\
\hline 33 & PRM-1@ & 31.33 & 84.66 & 6.11 & 3.07 & 9.19 & 0.173 & 0.091 & 796.77 & 7.91 & 36.12 \\
\hline 34 & PRM-2@ & 42.00 & 90.00 & 7.35 & 4.70 & 12.50 & 0.187 & 0.095 & 1084.78 & 8.58 & 46.66 \\
\hline \multirow[t]{7}{*}{35} & VL-149@ & 35.00 & 82.66 & 5.44 & 3.50 & 8.94 & 0.190 & 0.086 & 739.41 & 7.15 & 45.19 \\
\hline & GM & 36.00 & 82.00 & 5.90 & 3.81 & 9.72 & 0.186 & 0.081 & 801.43 & 6.65 & 43.79 \\
\hline & CV (\%) & 4.31 & 2.57 & 0.49 & 1.55 & 0.88 & 4.655 & 3.184 & 2.68 & 5.33 & 5.55 \\
\hline & $\operatorname{SEM}( \pm)$ & 0.77 & 1.05 & 0.01 & 0.02 & 0.04 & 0.004 & 0.001 & 10.74 & 0.17 & 1.21 \\
\hline & CD at $5 \%$ & 2.18 & 2.95 & 0.04 & 0.08 & 0.12 & 0.012 & 0.003 & 30.14 & 0.49 & 3.40 \\
\hline & Lowest & 25.33 & 70.00 & 4.10 & 2.20 & 6.97 & 0.128 & 0.057 & 493.06 & 4.67 & 34.48 \\
\hline & Highest & 52.66 & 96.66 & 7.89 & 4.99 & 12.89 & 0.287 & 0.131 & 1177.85 & 11.47 & 54.47 \\
\hline
\end{tabular}

Table.3 Estimation of correlation coefficient between all the seed quality traits in Finger millet (Elusine coracana (L.) Gaertn.) genotypes

\begin{tabular}{|c|c|c|c|c|c|c|c|c|c|}
\hline Characters & $\begin{array}{c}\text { Standard } \\
\text { germination }(\%)\end{array}$ & $\begin{array}{c}\text { Root } \\
\text { length } \\
\text { (cm) }\end{array}$ & $\begin{array}{c}\text { Shoot } \\
\text { length }(\mathrm{cm})\end{array}$ & $\begin{array}{c}\text { Seedling } \\
\text { length }(\mathrm{cm})\end{array}$ & $\begin{array}{c}\text { Seedling } \\
\text { fresh } \\
\text { weight }(\mathrm{g})\end{array}$ & $\begin{array}{l}\text { Seedling } \\
\text { dry } \\
\text { weight (g) }\end{array}$ & $\begin{array}{l}\text { Seedling } \\
\text { Vigour } \\
\text { Index-I }\end{array}$ & $\begin{array}{l}\text { Seedling } \\
\text { Vigour } \\
\text { Index-II }\end{array}$ & $\begin{array}{c}\text { Relative } \\
\text { growth } \\
\text { index (RGI) }\end{array}$ \\
\hline First count $(\%)$ & $0.8808 * *$ & $0.3271 *$ & $0.3794 *$ & $0.3746^{*}$ & -0.1275 & 0.0219 & $0.6580 * *$ & 0.3161 & $0.9286 * *$ \\
\hline Standard germination $(\%)$ & & 0.2886 & $0.3727 *$ & $0.3479 *$ & -0.1747 & 0.0400 & $0.6929 * *$ & $0.3741 *$ & $0.6640 * *$ \\
\hline Root length (cm) & & & $0.6958 * *$ & $0.9484 * *$ & $0.4555 * *$ & 0.3162 & $0.8542 * *$ & $0.4148 *$ & 0.3018 \\
\hline Shoot length $(\mathrm{cm})$ & & & & $0.8860 * *$ & $0.3560^{*}$ & 0.1432 & $0.8286^{* *}$ & 0.2614 & $0.3569 *$ \\
\hline Seedling length (cm) & & & & & $0.4578 * *$ & 0.2719 & $0.9132 * *$ & $0.3859 *$ & $0.3478 *$ \\
\hline Seedling fresh weight (g) & & & & & & $0.7273 * *$ & 0.2632 & $0.6010 * *$ & -0.0490 \\
\hline Seedling dry weight (g) & & & & & & & 0.2349 & $0.9338 * *$ & 0.0072 \\
\hline Seedling Vigour Index-I & & & & & & & & $0.4672 * *$ & $0.5421 * *$ \\
\hline Seedling Vigour Index-II & & & & & & & & & 0.2322 \\
\hline
\end{tabular}


An overview of the experimental results of present investigation indicated a wide spectrum of variation with respect to seed quality parameter among all the thirty five diverse genotypes of finger millet. The analysis of variance revealed highly significant among the genotypes for all the seed quality traits. Genotype IC-308884 showed highest seedling length, vigour indexI and vigour index-II among all the genotypes. Correlation coefficient depicts that the prior assessment of standard germination, seedling dry weight and seedling vigour index of the seed lot in any genotype could be used to predict the yield potentiality of that genotype in open field conditions.

\section{References}

Anderson, T.W. 1958. An introduction to multivariate statistical analysis. John Wiley and Sons, New York. Pp. 374.

Briggs, K.G. and Aylenfisu, A. 1979. The effect of seedling rate, seeding date and location on grain yield, maturity, protein percentage and protein yield of some spring wheat in central Alberia. Canadian J. Plant Sci. 59: 1129-1146.

Deshraj. 2002. Studies on viability and vigour in coriander (Coriandrum sativum L.). In: M.Sc. Thesis, submitted to $\mathrm{CCS}$ HAU, Hisar.

ISTA, 1996. International rules for seed testing. Seed Sci. Technol. 24: 355362.

Krishnappa, N., Chandrakanthappa, Kammar, Lokesh, K. and Narayanaswamy, S. 2001. Evalution of finger millet varieties for seed quality characters. Curr. Res. 39(5/6): 93-94.

Kumar, V., Malik T.P., Tehlan, S.K. and Kumar, A. 2017.Association among Various Seed Quality Parameters in Coriander. Int. J. Pure App. Biosci. 5 (1): 876-883

Kumar. D., Tyagi, V., Ramesh, B. and Pal, S.
2010. Genetic diversity in finger millet (Eleusine coracana (L.) Gaertn). Crop Imp. 37(1):25-28.

Kumari, S., Singh, S.K., 2015. Assesment of genetic diversity in promising finger millet [Eleusine coracana (L.) Gaertn] genotypes. The Bio. 10(2): 825-830.

Maiti, R.K., Mooreno-Limon, S. 2002. Seed and seedling traits in french bean (Phasiolus vulgaris) and its relation to abiotic stress resistance. Legume Research. 24: 211-221.

Misra, A.N. 1990. Seedling vigour and prediction of drought resistance in pearl millet genotypes (Pennisectum americanum L., Leeke). Beitr. Tropisch. Landwirtsch. Veternarmedizin. 28: 155-159.

Misra, A.N., Biswal, A.K. and Misra, M. 2002. Physiological, biochemical and molecular aspects of water stress responses in plants and the biotechnological applications. Proc. Nat. Acad. Sci. India. 72: 115-134.

Negi, S., Kumar, V. and Bhatt, A. 2018. Character association and path analysis for yield and its related traits in finger millet (Eleusine coracana (L.) Gaertn) genotypes. J. of App. and Nat. Sci. 9(3): 1624-1629

Owere, L., Tongoona, J., Derera, J. and Wanyera, N. 2015. Variability and traits relationships among finger millet accessions in Uganda. U. J. of Agri. Sci. 16(2): 161-176.

Pandey, P.K. and Kumar, G.S. 2005. Finger Millet: A flair for human nutrition in Uttaranchal. Ind. Far. Dig. 38(9): 2830.

Panwar, A., Mishra, A.C., Negi, S. 2018. Correlation studies on seed quality, pod and seed yield in germplasm of pea (Pisum sativum L.). Int. J. of Bio. S. Manag. 9(1): 98-102.

Punia, R.C., Dahiya, O.S. and Kumar, A. 2006. Exudate PH test : A quick and 
reliable predictor of seedling establishment in India Mustard [Brassica juncea (L.) Czern and Coss]. Natnl. J. Pl. Improv. 8(2): 103105.

Tzortzakis, N.B. 2009. Effect of pre-sowing treatment on seed germination and seedling vigour in grain amaranthus. Hort. Sci. 36(8): 117-125.

Ulaganathan, V. and Nirmalakumari A. 2014.
Genetic variability and correlation studies for quantitative traits in finger millet [Eleusine coracana (L.) Gaertn] germplasm. Int. Quarterly Jour. of Enviro. Sci. 5(6): 21-25.

Yadav, S.K. and Dhankar, B.S. 2001. Correlation studies between various fields parameters and seed quality traits in okra cv. Versha uphar. Seed Res. 29(1): 84-88.

\section{How to cite this article:}

Shivangi Negi, Vineet Kumar and Abhishek Panwar. 2019. Correlation studies on seed quality traits in diverse genotypes of finger millet (Eleusine coracana (L.) Gaertn). Int.J.Curr.Microbiol.App.Sci. 8(09): 737-744. doi: https://doi.org/10.20546/ijcmas.2019.809.088 